\title{
O OLHAR ENVENENADO: A PERSPECTIVA DAS PLANTAS E O XAMANISMO VEGETAL JAMAMADI (MÉDIO PURUS, AM)*
}

\author{
Karen Shiratori ${ }^{1}$ \\ ${ }^{1}$ Universidade de São Paulo, São Paulo, SP, Brasil
}

Ecce gratum et optatum Ver reducit gaudia, purpuratum floret pratum,

Sol serenat omnia.

(Canções de Beuern)

\section{Uma rotação de perspectiva}

Ao longo do trabalho de campo entre os Jamamadi, povo indígena de língua arawá $^{1}$ que habita a região do médio Purus (estado do Amazonas), foram frequentes os pedidos para ver as fotografias que eu havia levado de minha família, em especial, uma de minha irmã no Jardim Botânico do Rio de Janeiro. Trata-se de um retrato no qual ela está diante de uma paisagem de vegetação de mata atlântica. Ao verem a imagem, eles primeiro me perguntaram quem era a moça na foto para, em seguida, passar a fazer incontáveis perguntas sobre as plantas que estavam atrás dela. O que chamava a atenção deles não era o que para mim estava no primeiro plano, minha irmã, mas tudo o que estava atrás servindo de fundo, de cenário, uma paisagem inconspícua que me parecia desvinculada e arbitrária em relação ao sujeito da foto. Eles queriam saber se aquelas plantas eram nossas, quer dizer, se nós as havíamos plantado. Diante da minha negação, eles perguntaram quem as havia plantado, de quem eram aquelas plantas, porque não fazia sentido, ou até pior, seria uma enorme falta de respeito tirar foto com plantas de outra pessoa. Eles também queriam saber os nomes de cada uma das espécies que apareciam no retrato. Como eu não sabia nenhum, o estranhamento 
deles só aumentava, afinal, qual a razão de tirar foto com plantas de algum desconhecido sem ao menos saber identificá-las? Tentei explicar que se tratava de um jardim público plantado há muitos anos, um local de visita onde as pessoas vão passear, entretanto, somada às dificuldades linguísticas, a ideia de que um local cultivado por alguém seja público e aberto ao olhar de qualquer pessoa não fazia o menor sentido.

O desencontro do meu olhar com o deles tornou patente o equívoco entre os modos como eu e os Jamamadi compreendíamos as relações entre humanos e plantas. Uma rotação de perspectiva era imprescindível para que o fundo ganhasse forma e as plantas fossem para o primeiro plano da análise, abandonando o posto de paisagem/cenário. O que era um fundo verde disforme inesperadamente tinha tanto interesse, ou mais, que a pessoa presente na imagem. Identificar as espécies e saber seus nomes não eram, portanto, detalhes ou preciosismo etnográfico, longe disso, pessoas e plantas partilham de certa igualdade e reconhecer a importância deste fato era o ponto de partida para me relacionar com eles.

A anedota narrada revela não somente o abismo entre o meu conhecimento botânico e o dos Jamamadi, mas também ilustra uma distinção epistemológica, expressa nesta ideia de paisagem. Se, para mim, a importância atribuída à imagem estava concentrada no parentesco com a minha irmã, independentemente dos demais elementos da composição que, no limite, eram irrelevantes, para os Jamamadi, por outro lado, minha irmã não estava sozinha no retrato, e a presença das plantas pressupunha uma relação, uma proximidade insuspeita que justificaria a própria imagem.

Não custa lembrar que a atenção cotidiana despendida às plantas não se deve exclusivamente ao seu valor prático e econômico. Sua importância, para lembrar a ciência do concreto (Lévi-Strauss 2009 [1962]), não se justifica por elas serem "boas para comer", mas por serem "boas para pensar". E pode-se ir além, as plantas não se limitam a objeto da abstração humana, do impulso classificatório de ordenação do mundo, elas são boas para pensar eigualmente "boas para se relacionar" (Ingold 1991, 1992, torcendo um pouco a formulação do autor que se referia aos animais), quer dizer, as plantas não se restringem a metáforas para os processos sociais ou a um meio para a construção da pessoa. Neste sentido, o intuito central deste artigo será tomar o xamanismo vegetal jamamadi como via privilegiada para mostrar que a existência humana, para eles, é dependente, produzida e conceitualizada com as plantas.

Assim, abordo primeiramente a iniciação xamânica, cujo objetivo final é adquirir o noko koma, "o olhar envenenado". Mostrarei que os contornos deste xamanismo vegetal se fazem visíveis por meio da relação com as almas das plantas cultivadas, yamata abono, e das almas dos filhos e irmãos 
mortos, ai korimari, principais auxiliares que acompanham os pajés na prática terapêutica ou, em outra perspectiva, na defesa contra a ação predatória irrefreável da guerra mundial, conflito das diferentes gentes-plantas em curso no céu que transborda à terra. Será pertinente para o argumento pensar os limites da categoria biológica "planta" como ferramenta conceitual para analisar este contexto e, por fim, nuançar a caracterização do xamanismo amazônico nos termos de uma ideologia venatória, uma vez que a pregnância das plantas entre os Jamamadi propõe questionamentos mais amplos acerca do lugar prático-conceitual atribuído aos animais.

\section{Iniciação xamânica: fabricar um corpo venenoso}

O objetivo da iniciação xamânica ${ }^{2}$ é produzir um corpo masculino que esteja apto a se deslocar entre os patamares do cosmo, celestes e subterrâneos, e comunicar-se com os diferentes seres que o conformam, pois, sendo efetivamente um multiverso, sua trama é composta de relações e virtualidade ${ }^{3}$. Durante o longo período em que permanece recluso, são introduzidas, em todo o corpo do noviço, as pedras xamânicas, aona ou yama, conhecidas regionalmente no Purus como arabani, termo que também pode designar metonimicamente o xamã (Bonilla 2007; Maizza 2012; Huber 2012; Aparício 2017; Rangel 1994). O pajé mais velho, inawa bote, responsável pela iniciação, succiona seu próprio corpo, em regiões distintas, e cospe suas pedras xamânicas que serão, em seguida, introduzidas em toda a extensão do corpo do rapaz em formação ou sopradas em suas narinas misturadas com rapé, substância essencial na iniciação, uma vez que é o excesso do tabaco que propicia a comunicação interespecífica, ou comutação perspectiva, com os outros seres, com destaque para os diferentes espíritos de planta, cultivadas e não cultivadas. ${ }^{4}$

O rapaz será mantido em reclusão nos arredores da aldeia, afastado do convívio com os parentes e, em particular, distante das mulheres, pois o cheiro e o olhar femininos, potencialmente afetados pela instabilidade cíclica promovida pelo sangue menstrual, são agressivos para o seu corpo debilitado. O afastamento da aldeia e dos vínculos de parentesco é uma prefiguração da futura condição ambígua do pajé. Enquanto as pedras não estiverem fixadas e estáveis, o noviço não poderá sentir cheiros fortes, "catinga" na fala regional. Assim, antes de comer qualquer alimento, ele deve cheirar rapé para neutralizar o odor da comida e evitar que ele afete suas pedras recém-introduzidas. A instabilidade das pedras torna seu corpo vulnerável, o que implica o controle estrito de suas ações para impedir que elas se desprendam e retornem ao corpo de seu preceptor. Por estes motivos, 
o local onde o noviço é mantido recluso tende a ser pouco frequentado pelo medo das pessoas de pisar em alguma pedra que tenha se desprendido inadvertidamente de seu corpo.

O pajé mais velho utiliza-se de seu inalador, firi, feito com o fêmur do gavião real (Harpia harpyja), para soprar rapé, sina, tanto quanto o rapaz for capaz de suportar. Até acostumar-se com o efeito do rapé misturado às pedras, o rapaz irá vomitá-las. Esse efeito emético, embora colateral, não é de todo indesejado, pois atua na purificação de seu corpo, ação necessária para a boa fixação posterior das pedras. Os pajés salientam que diferentemente das pedras comuns, as xamânicas têm coloração amarelada e a consistência menos rígida - dizem que "é bonito e brilhante como o ouro". As pedras também podem ser referidas pelo efeito que provocam, por isso são chamadas yama kome, "veneno", "doença" ou "dor", de modo que a iniciação é entendida duplamente como adoecimento e envenenamento. $\mathrm{O}$ tabaco (Nicotiana tabacum) utilizado reforça a ideia de que a intoxicação é o meio através do qual o corpo do noviço adquirirá os aspectos apropriados para a atividade xamânica, quais sejam, a leveza imprescindível para que sua alma possa voar sem despencar do céu - alguns comparam as pedras "com os pilotos sem o quais o avião não voa" - a dureza de sua carne, própria dos corpos das almas de veneno, e o amargor associado às doenças.

É também pela ação do rapé que as pedras são estabilizadas no corpo, e é por meio delas que se torna possível a comunicação com as almas dos mortos, ai korimari; os espíritios inamadi; as almas dos cultivares, yamata abono, dentre diversos outros seres. São também as pedras xamânicas que permitem ao pajé visualizar os projéteis de feitiço no corpo de seus pacientes e extraí-los succionando-os, até cuspi-los materializados como flechinhas, ou retirando-os com as mãos, esfregando e pinçando o corpo para, em seguida, assoprá-los para longe ou de volta para o corpo do agressor. A substância xamânica, neste sentido, é um modo de objetificar ou materializar as capacidades do pajé, seus poderes e conhecimentos.

Aproximando-se o fim de sua reclusão, o noviço será testado algumas vezes. O pajé mais velho mandará o rapaz seguir por um varadouro e esperar sentado sobre uma árvore caída no caminho. O rapaz obedecerá e aguardará calado até escutar a aproximação do yomahi nemekaro, a onça celeste, que chega cumprimentando-o em jamamadi: kobonebonane, sotatiliahi!, "olá, não se assuste!". A onça pedirá ao rapaz que tire a sua camisa para poder lamber o seu corpo e, com a língua, introduzir suas pedras xamânicas. Trata-se da forma visível e objetificada da onça, yomahi, um espírito auxiliar, que vive no interior do corpo do pajé e que, projetada, se revela ao noviço como uma enorme onça branca. Inawa yomai towawaha, ai towa wama, "o pajé se transforma em onça, é gente transformada", eles explicam. 
O encontro decisivo para testar o bom andamento da iniciação xamânica ocorre com as almas das plantas. O procedimento é o mesmo: o rapaz seguirá sozinho por um varadouro, por ordem de seu preceptor, até encontrar um tronco caído sobre o qual irá esperar até escutar vozes se aproximando. Em seguida, ele conhecerá muitas almas de plantas, espíritos auxiliares do pajé, com as quais irá conversar e das quais receberá uma fruta ou um cultivar trazido do céu e que, por não crescer na terra durante o período do ano de sua iniciação, servirá de prova da veracidade de suas palavras e comprovará o término de sua formação. A partir de então, o xamã novo, inawa yati, estará apto a viajar para os patamares subterrâneos e celestes em busca das almas capturadas dos enfermos. Quando o pajé for encontrá-lo no caminho, o rapaz lhe entregará a planta e dirá: "este cultivar foi a alma que me deu".

A introdução de diferentes venenos vegetais no corpo do pajé noviço é o momento decisivo que encerra sua iniciação. Por seus riscos evidentes, é nesta etapa que muitos desistem e acabam não completando sua formação. Se é verdade que o objetivo da iniciação é fabricar um corpo envenenado, aspecto definidor da condição do pajé entre os Jamamadi, então, o uso dos venenos e a intoxicação controlada por meio do tabaco, além de diferentes outras plantas, são os meios para tanto. Com efeito, o pajé é aquele que possui o noko koma, o rosto com veneno; saliento que a ênfase é dada no sentido metonímico da expressão, de modo que a melhor tradução seria o olhar envenenado, posto que é através dos olhos que a peçonha do pajé extravasa seu corpo projetando-se como "raio", "faísca" e "luz de lanterna", eles comparam. Não ceder aos venenos, mas incorporá-los de modo a conferir ao pajé as características substantivas e agentivas das espécies vegetais, notadamente os venenos usados na caça, na pesca e aqueles das plantas cujos duplos humanos são reconhecidamente xamãs poderosos, é o objetivo deste procedimento.

Tendo em vista a força de cada veneno, o preceptor determina o modo como cada um será utilizado: a casca do cedro aguano (Cedrela fissilis), wifi, cujo amargor é a expressão sensível da agressividade e da potência do duplo desta árvore, será mascada; o timbó (Deguelia utilis), kona, e o iha (Strychnos solimoesana) serão bebidos em pequenas quantidades; com o bicafa (há dois tipos Curarea toxicofera e Abuta splendida), o barafa (Guarea grandifolia), o yakiyokari (não identificado) e o boa (Duguetia asterotricha), que compõem o veneno usado na caça, o noviço lavará o seu rosto "igual fazemos com sabonete", para impregná-lo com eles; outras plantas podem ser usadas, segundo a escolha do pajé para aumentar a potência dos venenos - como a Guarea carinata (família Meliaceae) e a 
caferana (Picrolemma sprucei) (cf. Prance 1978). O enrijecimento do corpo do noviço decorre da ação dos venenos, um sinal da transformação em curso e um alerta para ser cauteloso no trato com ele; mais ainda, recomenda-se evitar o contato físico, como os apertos de mão, para não correr o risco de ser enfeitiçado/envenenado. O costume dos brancos de cumprimentar com apertos de mão e abraços ${ }^{5}$ é encarado com certo mal-estar pelos Jamamadi mais velhos, sempre desconfiados de que o contato físico com desconhecidos possa introduzir feitiço em seus corpos. ${ }^{6}$

Apesar de estarem espalhadas por todo o corpo, como dito, o rosto é o local de maior concentração das pedras; o seu excesso transborda através dos olhos, por isso não se deve encarar diretamente um pajé. O coração, atibonokori, como sede do conhecimento/pensamento, também é outro ponto de concentração das pedras xamânicas. Não à toa, quando o pajé fala de seu saber, geralmente o faz apontando para o próprio peito.

O contato direto é a forma mais evidente de contágio, contudo, o feitiço pode ser lançado à distância pelo pajé quando este sopra sua pedra xamânica através de seu inalador, comparado à zarabatana, karaboha. Ao lançar sua pedra, ela se projeta fazendo-se visível como um dardo de feitiço, uma pequena flecha chamada sereini. Todavia há ainda outras formas de agressão xamânica: a introdução das pedras na comida ou em objetos que serão utilizados pela vítima; pela extrojeção dos animais contidos no corpo do pajé, em particular a onça e a cobra; por intermédio dos espíritos auxiliares aos quais pode ser delegada a tarefa de soprar feitiço nos desafetos; sem contar a diversidade do arsenal bélico que capaz de ser mobilizado no caso de conflitos que envolvam aldeias de diferentes gentes-planta ou de diferentes patamares cósmicos, como abordarei adiante acerca da guerra mundial. Não custa lembrar que os desdobramentos de tais eventos implicam que sejam analisados considerando-se perspectivas não totalizantes nem coincidentes, pois, à medida que o sopro do feitiço tem o efeito correlato do roubo da alma-coração, a agressão xamânica decorre igualmente de uma decalagem imprevisível de pontos de vista.

Segundo contam, a prova final a que é submetido o pajé recém-formado é curar um doente extraindo-lhe as flechas de feitiço por meio da sucção de seu corpo para, em seguida, cuspi-las e mostrá-las ao paciente. Antes de iniciar o tratamento, o pajé inala uma dose de rapé a fim de chamar seus espíritos auxiliares que o acompanharão nos procedimentos. Comparado ao celular, o rapé "ativa" a comunicação com as almas que vivem no céu e permite, através das pedras do corpo do pajé, tornar visível o feitiço no corpo do paciente. Inspecionando o local dolo- 
rido, o pajé apalpará o corpo até localizar o objeto a ser chupado, o qual, ao ser retirado, materializar-se-á como flecha, espinho, dente, prego etc. Em companhia das almas que chamou para ajudá-lo, o pajé lhes entrega o feitiço e pede para que procurem o responsável pela agressão, o dono do feitiço, para que vinguem seu paciente.

Os deslocamentos entre o céu e a terra exigem muito do corpo dos pajés que, por isso, não podem ser muito velhos. Contam que o "ouvido dói quando viaja" e "às vezes, sai sangue do nariz [por causa da pressão]". "Tem que ser forte para os ossos não quebrarem quando pula para a terra", explica um dos pajés jamamadi. Ter dentes é igualmente importante para puxar mais facilmente o feitiço do corpo do doente, o que dificulta a atuação dos pajés idosos.

O envelhecimento dos pajés, somado à falta de interesse crescente dos mais jovens em passar pelas duras provações da reclusão relegaram atualmente as iniciações xamânicas à vida póstuma. ${ }^{7}$ Geralmente, a pedido de um pajé vivo, a alma do parente morto será entregue a uma alma de planta de veneno celeste para que ela se encarregue da iniciação. Koeto, um dos filhos do pajé jamamadi mais atuante hoje, quando faleceu, teve sua alma levada ao céu por fowa abono, uma alma de mandioca que fora cultivada no roçado de seu pai. Fowa abono entregou a alma do rapaz para que os missionários tratassem de sua saúde e, após recuperado, a alma de Koeto foi entregue aos cuidados de uma alma de veneno iha para que ela o iniciasse. Ao longo do processo, a alma de Felipe, seu irmão mais velho falecido há alguns anos, também soprou rapé na alma de Koeto até que seus olhos "espocassem" (estourar na fala da região) de veneno ${ }^{8}$ e eles ficassem com o noko koma. Hoje, contam que a alma de Koeto terminou sua iniciação e é um importante espírito auxiliar de seu pai, acompanhando-o em suas viagens celestes.

Porém, não são apenas os conflitos que motivam os deslocamentos dos pajés; visitas, reuniões e festas costumam juntar as aldeias terrestres e as celestes, as almas dos vivos, dos parentes falecidos e das plantas. A agricultura celeste é reconhecida por produzir roçados prodigiosos, as almas plantam todo tipo de cultivar e, quando estes amadurecem, em particular a banana comprida, sibati bili, e a pupunha, yawida, são preparados, em abundância, o mingau de banana, sibati fene, e a bebida fermentada de pupunha, yawida fene, que reúnem aldeias distantes ao longo de vários dias. Em tais ocasiões, além de beber e festejar, os pajés vivos aprendem novos repertórios de cantos, uma vez que cantar não faz parte de sua formação no período da iniciação. As almas também participam dos rituais nas aldeias dos vivos; o trânsito entre céu e terra é um 
fluxo constante de pajés e almas, caminhos celestes e terrenos entrecruzados. Em 2013, durante o ritual pubertário, ayaka, um grupo de almas veio a convite do avô de Damares que estava em reclusa.

O pajé toma rapé e vai para o céu aprender os cantos. O que ele canta, ele aprendeu com os espíritos inamadi. É como se ele estivesse no telefone, ele conta o que ele está ouvindo, o ritual que está acontecendo lá. O chefe dos inamadi autoriza e o pajé vai aprender as músicas lá. Quando tem festa aqui é igual. O pajé vai para o céu antes e convida os espíritos inamadi. Ele vai pegar "ficha", pois precisa de autorização para trazer eles. Os inamadi "filmam" os Jamamadi para mostrar no céu para os outros. Vieram quatro pessoas [espíritos de plantas e mortos] para filmar a festa, eles usaram uma máquina semelhante a uma televisão. O cacique geral aqui também dá autorização para eles virem. Na festa, um inamadi tinha o cabelo comprido, loiro, ele era bem bonito, não usava cocar mas um pano na cabeça. Outro era parecido com os Jamamadi. Também veio o finado Funaya e o filho do pajé B., o João. O chefe deles nessa época era o Irimao abono, a alma do limão (Salgado Jamamadi 2013).

\section{Noko koma: o olhar envenenado}

Impregnar-se de veneno é, portanto, a marca da condição ambivalente do pajé jamamadi, cuja composição corporal aproxima-o dos duplos ou almas das plantas, permitindo que se comunique com elas "sem ter medo nem vergonha" e que seja comparável em virtude de ter se tornado "um tipo de veneno, que mata tudo". A fala que encerra um mito sobre o antigo pajé jamamadi Wiyonama apresenta de forma concisa esta ideia: "Eu vou acabar com todos vocês. Eu sou como o kona, timbó! Todos os peixes não morrem quando se coloca kona na água? O kona abono, alma do timbó, quando lava suas mãos, põe seu veneno na água e mata tudo [esta é a perpectiva da alma do veneno sobre a pescaria dos vivos com uso do timbó]. Eu sou o veneno, yama kome!" (cf. Shiratori 2018:110-111).

Além de ser rude encarar alguém com insistência, nokotoni(M)/nokotone (F) (v.t. noko, rosto/olhos; to-, para lá;-ni/-ne, continuativo), tal gesto é imprudente por desafiar a recomendação profilática básica de desviar os olhos, nos quais se concentra a potência xamânica. Se é verdade que o olhar é o veículo de transmissão de males entre os Jamamadi, então, saber o que deixar visível, o que manter oculto e estar atento para onde direcionar o olhar são atitudes imprescindíveis para não adoecer ou ser 
alvo de feitiços. Noko koma tiwara awalayaho, "você não pode encarar um olhar envenenado", recomendam os mais velhos às crianças desajuizadas.

Como descrito antes, conforme as pedras xamânicas são inseridas ao longo da iniciação, o corpo do pajé torna-se venenoso; seus olhos em particular são o índice de sua agência xamânica. Tanto é assim que pajés míticos, lembrados por suas capacidades excepcionais, mantinham os olhos fechados a fim de evitar a destruição descontrolada do mundo. Algumas almas de plantas, como aquelas da taboca teke (não identificada), uma das mais agressivas, ficam com os olhos apenas entreabertos, pois seu olhar, mesmo que de relance, é suficiente para fulminar quem cruzar seu caminho. "Não sobraria ninguém em Lábrea", fantasiava Arnica Jamamadi sobre os estragos que teke causaria se fosse à cidade.

Passivas ao potencial agressivo dos olhares alheios, as pessoas enfermas ou em recuperação são mantidas fora da visão de seus parentes a fim de evitar que piorem. Feridas, cortes e sobretudo picadas de cobra requerem atenção ao olhar potencialmente alterado que possa agravar o adoecimento e retardar a recuperação. O olhar das mulheres grávidas, menstruadas ou das meninas em reclusão é sobremaneira perigoso para os doentes e os pacientes em convalescência. ${ }^{9}$

Entre os Suruwaha, Huber nota que se atribui ao olhar um efeito destrutivo, em virtude da zubi gagini, "contagiosidade dos olhos" (2012:268). Pessoas em situações liminares, tais como os adolescentes que passam pelo ritual de iniciação, são obrigados a cobrir os olhos com envira, no caso das mulheres ${ }^{10}$, ou a olhar para cima, no caso dos homens. Fitar plantas recém-brotadas ou filhotes de animais de criação são atitudes censuradas, em especial no que se refere às mulheres grávidas. Ao contrário dos Jamamadi, entre os quais contemplar os cultivares, os animais de criação e as crianças pequenas produz seu bom crescimento, entre os Suruwaha, esse olhar demorado gakia-, gakyza- ou gai kijaha- faz secar os cultivares no roçado e pode matar os animais de criação (Huber 2012).

Quando as pessoas terminam de plantar a pupunha, plantam o tabaco. No primeiro mês após plantarem o tabaco, não olham para ele. Só têm costume de olhar para ele depois de alguns meses. Enquanto as plantas do tabaco estão recém-brotadas e as pessoas vão ao roçado, não se aproximam delas e olham para o outro lado (gatukwa-). Se olharem, a planta seca feita vítima da contaminação dos olhos (zubi gagini bahini). As pessoas não olham suas plantações após terminar o plantio. Só olham quando o tempo da colheita se aproxima (Xabi, maloca de Wahidiani, 13/06/09) (Huber 2012:269). 


\section{Os espíritos das plantas cultivadas}

Diz-se que cada forma de vida vegetal, não somente as plantas cultivadas pelos Jamamadi em suas roças e aldeias, possui um duplo humano, visível para os xamãs e os mortos, chamado abono - assim, o duplo da castanha é o mowi abono; da temida taboca teke, é o teke abono; do milho, é o kimi abono etc. O termo abono ${ }^{11}$ assume um sentido derivado ou secundário de "gente", "povo", "etnia", "grupo local", de modo que mowi abono, teke abono e kimi abono podem delimitar um intervalo ou limite semelhante aos "subgrupos" e ser entendidos também como "gente-castanha", "gente-teke" e "gente-milho" (alternativamente, pessoal da castanha, do teke e do milho).

Costuma-se comentar a aparência física destes duplos, seus hábitos alimentares, seu comportamento, sua força física e seus poderes xamânicos. O mesmo não se diz dos animais aos quais não se atribui agência semelhante àquela das plantas; a importância simbólica deles é limitada a certas espécies e a contextos relacionais específicos ${ }^{12}$. É importante salientar que a capacidade de assumir um ponto de vista humano não se restringe às espécies cultivadas pelos Jamamadi; pode-se afirmar que, no limite, a todas as formas de vida vegetais se atribui uma alma, um abono ${ }^{13}$.

Os yamata abono são as almas das plantas cultivadas, tais como sibati abono, alma da banana, fowa abono, alma da mandioca, koyo abono, alma da macaxeira, sami abono, alma do abacaxi, irimao abono, alma do limão etc. O termo yamata refere-se aos cultivares, sobretudo aqueles plantados nos roçados. De maneira geral, significa "comestível" ou "comida". E é a relação de criação - nawada (enfatizando a causa eficiente deste ato) ou nayana (no caso de salientar a causa final) - estabelecida com estas espécies que conforma os vínculos centrais de filiação entre as almas das plantas e o pajé para o xamanismo jamamadi.

A distinção entre plantas cultivadas e não cultivadas precisa ser matizada, uma vez que a diferença entre roça, floresta e capoeira é sempre definida segundo um ponto de vista, a partir de um sujeito, afinal, as espécies que os Jamamadi não cultivam, ao invés de serem consideradas "selvagens", são igualmente entendidas como cultivadas, a diferença é que o são por outros seres, em especial uma classe de espíritos chamados inamadi, os espíritos das cobras (maka abono), e os dafi (entidade patogênica semelhante a um boi). Cultivado e não cultivado, portanto, não são classificações absolutas, pois se a agricultura não é um atributo exclusivo dos humanos nas cosmologias multinaturalistas, a delimitação entre roça e floresta/mato ${ }^{14}$ depende do sujeito que a classifica, o que sugere a importância de não confundi-las a ponto de criar uma continuidade perigosa 
entre espaços habitados por diferentes seres, como bem lembrou Oliveira: "em um lugar onde a humanidade não é um atributo exclusivo dos homens e todas as gentes cultivam suas roças, é fundamental cindir o que é roça e floresta para cada sujeito" (2016:130).

A delimitação do espaço da aldeia, tabora, e do roçado, fadara, em oposição ao mato, yama kabani, no qual vivem os espíritos inamadi e as plantas não cultivadas - lembrando que a distinção entre cultivada e não cultivada ${ }^{15}$ é tênue e que nem todas elas têm um duplo agressivo - é incessantemente refeita no trabalho diário de capinar (yowi na) os terreiros e limpar (namosa) os roçados e caminhos da aldeia ${ }^{16}$. Todavia, os limites entre a aldeia e o mato, ou entre o doméstico e o selvagem, não são definitivos, pois pode acontecer de uma espécie considerada agressiva, não cultivada/não plantada, ser encontrada dentro dos limites da aldeia, às vezes nas imediações de uma casa e, ainda assim, ser mantida. Aceitando a presença dúbia de uma espécie que não se sabe quem plantou - quem é o dono (hiyi) -, eles preferem plantar um de seus cultivares próximo a ela para vigiá-la e proteger os moradores da aldeia ao invés de cortá-la.

Voltando aos cultivares agrícolas, uma classificação utilizada pelos Jarawara (Maizza 2012) para ordenar suas plantas baseia-se na cadeia hierárquica que as ordena da mais forte à mais fraca, de acordo com a força associada à sua fisicalidade (relativa ao seu porte, ao tamanho de seus troncos, à presença de espinhos etc.) e à sua fisiologia (propriedades medicinais e terapêuticas). Deste modo, o tingui seria a planta mais forte, seguida da pupunha, do algodão e, por fim, do cará. As árvores também se organizariam da mais forte à mais fraca: siro (uxi), wakaro (não identificada), ora (jenipapo), mato (pequiá), por fim, o tokowisa (não identificada). A autora nota que a força de cada espécie influencia o modo como ela será consumida, crua ou cozida. No caso dos Jamamadi, a experiência pessoal e a relação que se cultiva com a espécie vegetal individualmente são sobremaneira relevantes para definir suas virtudes xamânicas e características comportamentais. Das distintas classificações concorrentes, pode-se afirmar que não há em nenhuma delas uma ordenação estável que contemple todas as espécies numa sequência fixa, muito embora elas sejam comparadas e avaliadas de maneira circunstancial de acordo com sua "força" ou "dureza", kita, e seus aspectos corporais a fim de escolher a mais adequada para acompanhar o pajé ou para servir de alimento - cautela essencial para evitar feitiços ou o agravamento de uma enfermidade.

As classificações vegetais mobilizadas pelos Jamamadi enfatizam a força xamânica e as características morfológicas e morais, expressas em termos de bondade/beleza/limpeza (amosa), força/dureza/agilidade (kita ou 
kitama), maldade/feiura/sujidade (towe ou amosara), e fraqueza/lentidão (kitare ou hahamoranaro), do duplo humano da planta. As almas boas, bonitas e perfumadas andam vestidas e paramentadas com ornamentos tradicionais, consomem os produtos do roçado e os alimentos industrializados, compram mercadorias e possuem documentos; as almas ruins, feias e malcheirosas agem na ilegalidade, andam nuas, comem comida sem cozinhar ou estragadas e incitam as brigas da "guerra mundial" que está em curso no céu. As almas ruins, agressivas, em geral usam armas rudimentares se comparadas às espingardas, aos revólveres e às bombas utilizadas pelas almas benevolentes.

Justamente pela centralidade da experiência xamânica individual, as plantas não apresentam um traço essencial que permita a organização hierárquica fixa independente da relação estabelecida entre o xamã e a alma de planta. Muitos comentam a beleza da alma da mandioca (fowa abono), que tem sempre o rosto pintado, usa tanga e braçadeiras feitas com penas de arara vermelha. Apesar de não ser considerada forte, a mandioca é um dos yamata a quem mais se confia a tarefa de levar as almas dos mortos para o céu. Para alguns, a alma do tucumã (haso abono), cujo espinho é como uma flecha que provoca doenças graves, pode ser um espírito auxiliar confiável, outros o chamam de forma incisiva de safado e mulherengo; o mesmo se diz a respeito do duplo do caju (ayawa abono) uma alma considerada "boa", mas que pode agir circunstancialmente de maneira vingativa.

Os espíritos auxiliares que acompanham o pajé são escolhidos em conformidade com a tarefa que terão de desempenhar, ou seja, eles são chamados também tendo em vista suas habilidades específicas para lidar com os inimigos ou as condições em que o enfrentamento ocorrerá, portanto, a fisicalidade das plantas é um critério central nesta escolha. Se uma alma for capturada na água, é preciso chamar almas de plantas que saibam nadar; no caso da alma de um parente estar perdida na cidade, o mais indicado é que o pajé chame uma alma de planta que saiba falar português. Os poderes xamânicos estão parcialmente associados às características morfofisiológicas das plantas, porém, sua ação depende igualmente da relação do pajé com aquela alma e com sua face vegetal terrestre. A origem da planta - quem deu a semente ou muda (plantas jamais são compradas) - é igualmente relevante para definir suas capacidades agentivas, isto é, um timbó cultivado na roça de um xamã será mais potente que aquele do roçado de um jamamadi não iniciado no xamanismo, ou ainda, um limão cujas sementes vieram de Porto Velho conhecerá mais do modo de vida dos brancos que aquele cultivado na aldeia. 
Para resgatar a alma de um jamamadi que havia morrido em Manaus, contam que foram chamadas almas de plantas adquiridas na cidade porque elas sabem se deslocar no meio urbano e se relacionar com os brancos semelhante aos espíritos auxiliares vaso paumari ${ }^{17}$; os duplos do timbó, por sua vez, foram chamados para buscar a alma de um outro jamamadi que morrera afogado, pois eles são bons nadadores e conhecem os seres que vivem nas aldeias aquáticas. É preciso saber quais as plantas adequadas para lidar com o modo de vida, hábitos, força do agente patogênico.

A dedicação à atividade agrícola é, destarte, o que propicia a prática xamânica ao estabelecer as relações de filiação com as almas das plantas, ocasionalmente incorporadas aos pajés como espíritos auxiliares, que é a garantia das condições de possibilidade da cosmopolítica jamamadi. Diante deste quadro, faz sentido a proximidade com as casas e a abundância chamativa das plantas nas aldeias, onde elas crescem formando divisões, circunscrevendo os espaços dos diferentes núcleos familiares, não como muros alheios e externos - as chamadas cercas vivas - mas como parte integrante do parentesco que se estende para além do humano.

Contudo, a relação com as plantas não se restringe à esfera da convivialidade do cultivo/criação e da consanguinidade (cf. Descola 1986; Taylor 2000; Rival 2001; Oliveira 2012, 2016; Miller 2015; Morim de Lima 2017), pois o horizonte da afinidade é um resíduo jamais extirpado ${ }^{18}$. Os duplos das plantas podem passar da benevolência à vingança, dependendo da atenção aos cuidados necessários daquele que a plantou, chamado de abi, "pai". Se o pai cuida de seus cultivos juntamente com a ajuda de sua esposa e filhos, as almas das plantas retribuem mandando sua forma vegetal visível produzir frutos em abundância, além de protegê-los das almas que estão à espreita para roubar-lhes seus korimari. Conforme me explicou um pajé,

Adoecemos quando não cuidamos bem das nossas plantas. Não pode maltratar nem cortar. Tem que cuidar bem. "Minha mãe e meu pai cuidam de mim", a pupunha vai pensar. Aí, outra alma vem e ela manda embora, diz que não pode mexer com o papai dela. Também dá muita fruta para não deixar o pai e a mãe com fome.

Novamente, o roubo da alma é duplamente descrito como resultante da captura do coração da vítima pelo espírito inamadi - categoria ampla que abarca os duplos das plantas não cultivadas, as almas das cobras (maka abono), os dafi, além de uma grande variedade de espíritos humanoides disformes - que está caçando e que ao se deparar com um jamamadi o verá enquanto animal de caça, bani, ao passo que na terra a vítima cairá enferma por ação do feitiço introduzido em seu corpo; as dores, a inquietude e a febre 
são as manifestações do seu coração sendo moqueado. O inamadi flecha sua vítima para comê-la, as vísceras serão postas na beira do fogo para assar, aqui a atenção é dada ao coração, órgão entendido como semente/muda que precisa ser preservado para garantir a vida póstuma. É necessário que o pajé recupere a alma/coração - extraia as flechas de feitiço - antes que ela asse ou seja completamente devorada, ocasionando a morte definitiva da vítima ou a impossibilidade de que possa ser plantada para germinar nos roçados celestes.

\section{Guerra mundial das gentes-planta}

Destoando das imagens de calmaria e concórdia recorrentes no discurso cotidiano, há os relatos dos conflitos sanguinolentos em curso no céu que garantem, sem que pese contradição, as condições de possibilidade da vida. As plantas estão em guerra no céu, uma "guerra mundial", mas vale dizer que os conflitos transbordam para os demais patamares e seres, envolvendo-os num sistema de agressão xamânica e vingança infindável. Maizza descreve em termos semelhantes as relações entre as almas de plantas.

[...] o mundo da gente-planta é, antes de mais nada, um mundo de guerra, de inimigos, de disputas constantes entre os abono das plantas cultivadas contra os abono das plantas não cultivadas ou cultivadas por Outros: brigas das yama korona abono [alma de coisa plantada] contra os awa abono [alma de árvore] (Maizza 2014:504).

Nota-se a ocorrência dos enfrentamentos desta guerra através dos fenômenos meteorológicos e celestes: estrelas cadentes são bombas lançadas entre aldeias no céu; ventanias são efeito do pouso e decolagem dos aviões; tempestades, trovões e raios são explosões. A expressão "guerra mundial", utilizada em português, embora usada para se referir ao conflito entre as plantas, não exclui outros seres, apenas enfatiza seus principais envolvidos ou a fonte de onde emana a violência. É difícil retraçar a origem da expressão, uma hipótese seriam as imagens de guerra provenientes dos filmes de ação, agora abundantes nas aldeias. As descrições e as imagens se assemelham a uma guerra mundial por sua brutalidade e dimensão, uma vez que implica diferentes "mundos", "nações", "povos", "gentes", em suma, plantas, pois aqui a diversidade humana é expressa em termos de variações vegetais.

Os recursos bélicos mobilizados não ficam atrás daqueles dos filmes: bombas, armas de calibres variados, aviões, facas, além das armas tradicio- 
nais como terçados, lanças, zarabatanas, arcos, flechas e, claro, venenos, em particular aquele que se projeta do olhar dos pajés que têm o noko koma, o olhar envenenado. Nesta guerra de plantas, teme-se menos ser visto por um jaguar do que não conseguir se esquivar e se ocultar da perspectiva predadora de um olhar envenenado de planta.

Nos diálogos noturnos do pajé com seus espíritos auxiliares, ele pedirá notícias dos parentes falecidos e solicitará ajuda caso algum deles esteja enfermo, então, entregará a flechinha de feitiço retirada do corpo do paciente, ou ele mesmo irá carregá-la consigo em sua viagem para o céu onde irá manakonebonane19, "vingar-se", "dar o troco", ou brigar na guerra mundial, acompanhado de seus auxiliares. Novamente, toda agressão é uma vingança que se justifica como resposta a uma ação não iniciada pelos Jamamadi. Jamais escutei acusações de feitiçaria que pesassem sobre os parentes corresidentes. Ao que tudo indica, os feiticeiros são pajés vivos de outros povos, principalmente os vizinhos Jarawara e Paumari, ou de almas de plantas selvagens, não cultivadas. Não custa lembrar que os desdobramentos dos eventos requerem que sejam analisados segundo perspectivas não totalizantes, pois, uma vez seja soprado o feitiço, ele tem o efeito correlato do roubo da alma, a agressão xamânica implicando igualmente uma decalagem de pontos de vista (Viveiros de Castro 1996, 2002; Lima 1996, 2005).

\section{O que é uma planta?}

Uma breve digressão se faz necessária acerca da formulação conceitual deste argumento. Não há uma palavra em jamamadi para a categoria "planta"20, equivalente ao reino biológico plantae, ou um termo englobante o suficiente para abarcar tal diversidade vegetal. Seria necessário adentrar nas classificações botânicas nativas e em seus múltiplos critérios taxonômicos a fim de mostrar a inadequação de nossas categorias biológicas em sua abrangência e generalidade. Seja como for, os Jamamadi se referem às espécies vegetais baseando-se também em sua morfologia, na associação com espíritos, bem como em suas propriedades terapêuticas e toxicidade, além de mobilizarem as relações particulares que estabelecem com o duplo ou o aspecto humano de cada uma.

A distinção mais geral é entre as plantas que foram plantadas pelos Jamamadi, os yamata, e aquelas que ninguém sabe quem plantou, quer dizer, que crescem no mato, kabanika-ya, sem requererem os cuidados dos Jamamadi ou sem que tenham sido criadas por eles, como é o caso da maioria das árvores e palmeiras, awa. Quanto aos venenos, de maneira ampla são 
referidos como tehe, "veneno", "aditivo", "coisa adicionada", à semelhança do tempero que é acrescentado à comida; tanto é assim que dizem em português "temperar o veneno". O termo que utilizam para se referir aos animais tampouco é semanticamente análogo ao reino animalia. Os animais, em geral os mamíferos, são chamados de bani, que também significa "presa", "caça"; os pássaros seriam bani bidi ou "presas pequenas"; por fim, os peixes são chamados de $a b a$, termo que também é usado para a matrinxã, espécie paradigmática da categoria (Viveiros de Castro 2006:327-329).

Entende-se aqui por "planta" não a dimensão circunscrita, fixa, a um reino biológico, subsumida à noção de Natureza, mas sim a região ou parcela do cosmos altamente significativa na composição da pessoa, da socialidade e da humanidade, portanto, irredutível a um domínio natural. Acredito que para os Jamamadi não exista uma noção de planta não humana desprovida de subjetividade, semanticamente neutra e coextensiva à divisão do reino plantae. Para esta fitologia perspectivista não é possível determinar de antemão o que é uma planta somente ao recorrer à classificação taxonômica da biologia, ${ }^{21}$ pois tal categoria em sua colossal diversidade define-se de modo interespecífico ("becoming with" nos termos de Haraway 2008) e em interação.

Voltando à anedota que abre este artigo, deixar de ver as plantas sob o epíteto paisagem, um ruído de fundo das etnografias, é crucial para o argumento que construo. O ponto que interessa destacar é a ausência da objetivação de elementos não humanos da flora que produziria um espaço desumanizado, um ambiente composto de singularidades vegetais, externas às relações sociais. Reitero que minha intenção não é ponderar sobre a pertinência da noção de paisagem para os povos ameríndios das Terras Baixas da América do Sul, mas sim refletir sobre os efeitos teórico-conceituais provocados pelo reposicionamento das plantas no primeiro plano da análise, sem que estas formas de vida se subsumam à categoria animal ou a uma suposta centralidade humana. O experimento proposto, portanto, consiste em pensar a humanidade a partir dos aspectos materiais, morfo-fisiológicos e das elaborações metafísicas jamamadi sobre as plantas. Isto sem desconsiderar, evidentemente, o prazer estético que os Jamamadi demonstram em contemplar o desenvolvimento do roçado, em observar que os brotos e os botões escondem o vigor das grandes árvores, em admirar a beleza dos frutos maduros. Tais aspectos são um lembrete de que as questões biológicas são igualmente estéticas quando se trata de pensar a vida das plantas.

[o] que chamamos crescimento e destruição são as maneiras e as formas infinitas de dar-se forma. A vida vegetal é o dar-se forma. A vida que se abrevia no dar-se forma para si mesma. É o lugar onde cada problema biológico é problema estético, e cada problema estético é problema de vida ou de morte (Coccia 2016:212). 


\section{Xamã como horticultor}

Diante do exposto, decorre que o pajé jamamadi é um horticultor par excellence: a abundância da vegetação de sua aldeia é um indício de suas capacidades xamânicas, bem como a dimensão e a produtividade dos seus roçados. Assim sendo, vale para os Jamamadi a caracterização já feita por Maizza sobre o pajé jarawara segundo a qual "um bom xamã seria antes de mais nada um bom cultivador" (2014:506). É essencial que ele tenha muitos espíritos auxiliares, de diferentes espécies, visto que cada um é dotado de habilidades e forças específicas, o que implica dedicar-se sobremaneira às plantas. Os pajés visitam seus roçados diariamente para limpá-los, para conversar com as almas dos cultivares e para olhá-los, kakatoma, ação fundamental para o crescimento. ${ }^{22}$ A escolha da área para o novo roçado, a derrubada da vegetação e a queima são tarefas que cabem exclusivamente aos homens; até o plantio, a participação feminina limita-se aos cantos que são entoados à beira do roçado, sem adentrá-lo (cf. Shiratori 2018). Chegada a hora do plantio, a área é dividida entre os membros da família que ali farão, de forma interdependente, o seu roçado. A despeito de trabalharem juntos, o conjunto total das plantas ou partes que compõem o fadara, roçado, é referido como propriedade do pai que, no limite, é o seu dono, hiyi.

Isto se deve ao fato de as almas das plantas cultivadas na terra pelos Jamamadi estarem a eles vinculadas por laços de filiação, em outros termos, como seus filhos-planta, sendo preciso mantê-los seguros; tanto é assim que é desejável a presença de árvores de grande porte nas proximidades de um roçado para que protejam os cultivares em crescimento, o que sugere uma intrincada rede intersespecífica na qual diferentes espécies vegetais estabelecem aliança entre si. As almas das plantas, por sua vez, zelam por seus pais e irmãos, permanecendo sempre por perto para impedir que os espectros dos mortos se aproximem para assediá-los, para afastar os espíritos patogênicos e para matar as almas de plantas mal-intencionadas. A vegetação dos roçados e aquela que cresce em abundância perto das casas são fundamentais na garantia da segurança de seus moradores, de modo que sua presença não é nada fortuita. Em vista disso, o "caos" visual resultante da exuberância da vegetação que prospera em toda a aldeia não é fruto de negligência, pelo contrário, é meticulosamente produzido. Em suma, a presença numerosa das plantas é sinal de prodigalidade, de potência xamânica e de sucesso na produção do parentesco. 


\section{Considerações finais: a lógica venatória e o lugar das plantas no xamanismo}

A importância do universo vegetal para o pensamento jamamadi o singulariza dentro da paisagem etnográfica na qual a relação especulativa dominante dos humanos com o ambiente privilegia a fauna antes que a flora. Neste sentido, pelo fato de a antropologia jamamadi investir fortemente em esquematismos fitomórficos, ${ }^{23}$ fundamentando uma cosmologia na qual a vida das plantas e a vida dos humanos se espelham e se entrelaçam em múltiplas dimensões, tal particularidade etnográfica convida a uma reavaliação das imagens produzidas pela etnologia recente a respeito do universo conceitual dos povos amazônicos, sobretudo a ênfase dada ao mundo animal, tanto do ponto de vista prático (caça) como simbólico-cosmológico (mitologia, ritual, xamanismo) em detrimento de outras formas de vida, notadamente as plantas.

Convém observar as especificidades do xamanismo jamamadi em relação à "ideologia cinegética" (Viveiros de Castro 1996, 2002, 2015; Hugh-Jones 1996) basal da metafísica da predação, manifesta na valorização da figura do "animal" - não de quaisquer animais, mas daqueles cujos valores prático e simbólico são notórios - e na sua conexão ou continuidade com a guerra e a caça. No que se refere à articulação entre xamanismo e caça, bem como aos desdobramentos da atividade cinegética humana em guerra enquanto inversão perspectiva do ponto de vista das presas (Lima 1996, 2002), evidencia-se a pregnância simbólica da caça como aspecto essencial na formulação do perspectivismo ameríndio.

Não se trata, porém, de problematizar a atribuição de intencionalidade humana aos animais a exemplo de outras cosmologias que negam tal capacidade aos não humanos fora do registro mitológico (Overing 1985:249ss, 1986:245-246 citado em Viveiros de Castro 1996), embora este também seja o caso dos Jamamadi. Trata-se antes de reconsiderar o animal como "protótipo extra-humano do Outro" (Viveiros de Castro 1996:120), ou que o modo anímico seja característico das sociedades nas quais o animal é "foco estratégico de objetivação da natureza e de sua socialização" (Descola 1992:115), pois o que se segue é a desvalorização do papel das plantas, geralmente restritas aos domínios da convivialidade e da produção do parentesco, em suma, à esfera do idioma da consanguinidade. E na mesma levada, o silêncio reiterado sobre a floresta e as áreas de capoeira, como se as espécies "selvagens" estivessem desprovidas de importância simbólica, prática e ecológica.

Sabe-se que o perspectivismo não se aplica a todos os animais, mas incide mais frequentemente sobre as espécies de grandes predadores, como 
onças, serpentes constritoras e aves de rapina, animais carniceiros, como os urubus, bem como sobre as presas dos humanos, como queixadas, caititus, peixes etc. Por não se aplicar igualmente a todos os animais, focando-se na dimensão relacional entre presas e predadores, a predação constitui o contexto pragmático e teórico propício ao perspectivismo (Viveiros de Castro 2002:353). Não obstante a presença indelével das plantas nas cosmologias ameríndias, seu lugar é coadjuvante nas análises, quando não ocupada por uma versão animalizada. Considerar as espécies vegetais implica relativizar a valorização simbólica da caça em detrimento da horticultura, pois o peso cosmológico conferido aos animais obscurece, torna secundária ou derivada a espiritualização das plantas - o que não se aplica a todas as plantas, como registra Viveiros de Castro na seguinte nota: "nas culturas da Amazônia ocidental, em especial naquelas que fazem uso de alucinógenos, a personificação das plantas parece ser ao menos tão saliente quanto a dos animais" (2002:357, nota 14).

Numa versão jamamadi da formulação perspectivista sobre as relações entre humanos e plantas, o "protótipo extra-humano do Outro" não é o animal, mas a planta, de forma que a relação venatória-xamanística deve ser redimensionada em vista de uma reconceitualização ou reposicionamento das categorias em questão (lembrando que "animal", "vegetal" e "humano" não subsumem exatamente os mesmos conteúdos que nós supomos), equacionando-as no contexto de um xamanismo vegetal. Porém, se as plantas são o ponto de partida da reflexão, seria suficiente substituir "animal" por "vegetal", recalibrando e fazendo os devidos ajustes das ferramentas conceituais? As narrativas míticas, entendidas como processo de especiação, e os processos escatológicos, um retorno ou reecontro do tempo anterior às diferenças instituídas pela mitologia, notável na atração dos mortos pelos corpos vegetais, mostram que a conjungação de humanidade e de vegetalidade não é homóloga àquela entre humanidade e animalidade.

Vejamos, rapidamente, o que a mitologia acrescenta ao argumento. As narrativas míticas descrevem um estado originário de indiferenciação entre os seres humanos e os animais (outros seres e fenômenos podem ser incluídos). Cada espécie de ser aparece para si como humana e assim é vista pelos outros seres, apesar de já manifestar alguns de seus traços distintivos e definitivos enquanto espécie animal, vegetal, fenômeno meteorológico etc. Tal diferenciação intensiva entre natureza e cultura não se reduz um processo evolutivo que parte do animal para o humano, ou seja, que atribui precedência lógico-temporal à vida animal. A mitologia ameríndia trata, em geral, de como os animais perderam certos atributos que foram mantidos pelos humanos. Nestas transformações, a animalidade não é tomada como condição original partilhada por humanos e animais, pelo contrário, a humanidade é que constitui a condição basilar da existência. Seguindo essa 
formulação do perspectivismo multinaturalista (Viveiros de Castro 1996, 2002), os humanos seriam aqueles que continuaram iguais a si mesmos, por conseguinte, os animais seriam ex-humanos, e não os humanos ex-animais. A hipótese é que se introduzíssemos a categoria "vegetal" na formulação desta premissa, chegaríamos à versão jamamadi segundo a qual os animais são ex-humanos e os humanos seriam ex-plantas.

O desenvolvimento do raciocínio permanece o mesmo para a categoria animal equacionada à categoria humana, porém, ao incluir as plantas, a premissa é substancialmente alterada. Em resuno, a humanidade não é a matéria da qual teriam se originado os demais seres, de acordo com a mitologia jamamadi: os animais são aqueles que perderam sua humanidade e os humanos são aqueles que perderam a perenidade característica e definidora da existência vegetal (cf. Shiratori 2018). Contudo, segue valendo a distinção proposta por Descola segundo a qual "o referencial comum a todos os seres da natureza não é o homem enquanto espécie, mas a humanidade enquanto condição" (Descola citado em Viveiros de Castro 2002:356). Esse esclarecimento é central, não opera através de uma lógica histórico-evolucionista, pois não basta atribuir precedência às plantas sem questionar o que se entende por humanidade. A condição humana como ideal moral persiste como a constituição basilar em operação, não a humanidade enquanto espécie.

Acredito que a particularidade da formulação do perspectivismo em termos jamamadi é que a condição humana adviria das plantas, ou seja, a vegetalidade é a condição original comum a humanos, animais e vegetais. Se a humanidade (dos humanos) não é a substância primeva, na época do fluxo contínuo que permitia a comunicação irrestrita e a metamorfose, a partir das quais teriam se originado todos os seres do universo, qual seria a natureza dessa vegetalidade humanizada? Em que termos os Jamamadi formulam essa continuidade e quais as consequências ontológicas que se impõem ao seu modo de vida atual? Quais as implicações conceituais resultantes de se pensar uma ontologia que não considera a humanidade, e seus esquemas antropomórficos, como seu alicerce? Tendo sido outrora planta, os Jamamadi ainda manifestam resquícios destas características em sua onomástica, no processo de construção de seus corpos com substâncias vegetais durante os períodos de reclusão, no parentesco cultivado através das atividades agrícolas, na prática xamânica, nos rituais funerários etc.

A estrategia argumentativa de abordar o exemplo do pajé jamamadi é eloquente, pois demonstra por sua ambivalência ou a capacidade de perspectivar-se a si mesmo (Lima 1996, 2002) a atualidade da diferença vegetal original, oculta ou somente pressuposta como destino póstumo aos não iniciados, através da consubstancialidade parcial com as plantas 
venenosas. O olhar envenenado do pajé jamamadi é a manifestação da face vegetal da humanidade; que em sua atualização controlada reside a condição de possibilidade da política cósmica. A vegetalidade ou dimensão vegetal do humano, mantida como um fundo virtual, espitiritual e celeste, também se revela no fato escatológico de que o fim que os Jamamadi aguardam é ser plantado nas roças das almas de plantas, ser por elas criados e com elas se casar ${ }^{24}$, isto é, em concordância com o que propora Maizza (2012) para a existência jarawara em sentido lato, morrer é devir-planta. ${ }^{25}$

Assim, um dos objetivos de fundo deste artigo não foi pensar o que as plantas possuem em comum com os humanos, uma vez que a categoria vegetal não está subsumida à humanidade, trata-se justamente do oposto, o problema está em contraintuitivamente refletir sobre o que os humanos possuem em comum com as plantas. A existência vegetal precede a humana, que lhe é tributária. Que as plantas sejam humanas implica situações já bastante desenvolvidas pelo perspectivismo, mas o argumento avança para uma direção insuspeita: se a humanidade é subsumida, derivada ou apenas contingente em relação às plantas, o que isso modifica na relação?

Em consonância com o movimento de valorização da vida vegetal, avançamos para reconceitualizar o lugar atribuído às plantas e aos seus processos morfofisiológicos na etnologia indígena. E eis que a dignidade das plantas tal como vista através da relação com os Jamamadi oferece um contraponto potente ao discurso modernizador do agronegócio em sua ânsia predatória de transformar em desertos de soja e eucalipto as florestas, que é um nome para os mundos indígenas. Minha aposta é que, no encontro com as plantas, o pensamento possa afetar-se por sua vitalidade e, quem sabe, sem mais projetar sua razão sobre uma imagem idealizada, permita-se dar atenção à ontofitologia que anima o mundo.

Recebido em 19/02/2019

Aprovado em: 15/04/2019

Karen Shiratori

Pós-doutoranda do Departamento de Antropologia da Universidade de São Paulo e pesquisadora do Centro de Estudos Ameríndios (CEstA). Mestre e doutora em antropologia social pelo Programa de Pós-Graduação em Antropologia Social do Museu Nacional. Especialista em etnologia indígena com foco nos estudos de xamanismo, parentesco e organização social. Trabalha no sul do estado do Amazonas com povos falantes de línguas arawá e tupi kagwahiva. Também desenvolve pesquisas sobre políticas públicas e direitos territoriais voltados aos povos indígenas em isolamento.

E-mail: karen.shiratori@gmail.com 


\section{Notas}

* Este artigo sintetiza algumas ideias desenvolvidas na tese de doutorado $O$ olhar envenenado: da metafísica vegetal Jamamadi (médio Purus, AM), defendida em 2018, e esboça seus primeiros desdobramentos a partir do xamanismo jamamadi, considerando suas consequências político-filosóficas centrais. Ademais, este esforço está em consonância e se inspira num movimento mais amplo de reconceitualização e renovação do interesse pelo universo vegetal na antropologia e em diferentes disciplinas. Agradeço as contribuições oferecidas pelos pareceristas desta revista e as cuidadosas leituras e comentários de Oiara Bonilla e de Mauro dela Bandera; escusado lembrar que quaisquer equívocos são de minha responsabilidade.

1 Também fazem parte da família linguística arawá os Jarawara, os Banawá, os Paumari, os Deni, os Suruwaha, os Kulina e, ao que tudo indica, os isolados Hi-Merimã. Exceto os Kulina que habitam uma extensa área que vai do alto rio Purus, tanto do lado brasileiro como peruano, passando pelo alto e médio rio Envira até o rio Juruá e seus afluentes (Cerqueira 2015:18), os demais grupos arawá habitam a região média da bacia do rio Purus, no sul do estado do Amazonas.

2 Em virtude de obstáculos incontornáveis, os dados sobre a iniciação xamânica resultam de diferentes descrições que me foram feitas ao longo do campo: como mulher, jamais poderia acompanhar um processo de iniciação, embora minha condição de etnógrafa me conferisse vez por outra um estatuto ambíguo; soma-se ainda o fato de atualmente os Jamamadi serem iniciados somente em sua vida póstuma, o que tampouco pude acompanhar em primeira mão.

3 A ideia de um cosmo constituído e permeado por um excesso de agência está contida na análise cosmográfica elaborada por Maizza (2012) que fala, por isso, em "mundo perigoso". Zama zama é a expressão suruwaha (Huber 2012:204) para universo; a tradução literal "coisas das coisas"/ "coisas consistentes"/ "coisas concretas" revela o seu forte imanentismo. Em Jamamadi (Shiratori 2018) e Jarawara (Maizza 2012:57-59), yama, "coisa", é usado genericamente para qualificar as entidades em seu caráter concreto; em yama kabani, "floresta"/"mato", yama tem sentido de "espaço"; a reduplicação do termo, por sua vez, tem função semelhante àquela apontada por Huber para descrever o universo.

4 O rapé é composto pelas folhas do tabaco (Nicotiana tabacum) que são plantadas nos roçados em meio aos outros cultivares. Uma vez secas e piladas, acrescentam-se as cinzas da casca do cupuí (Theobroma subincanum) - hoko em jamamadi e diferentes línguas arawá - responsável pela força e potência da mistura. Os Deni possuem um rapé chamado baduhu-tsina composto pela planta Pyrenocarpous lichen. E os Paumari fazem rapés de uso ritual chamados koribo, compostos de tabaco (Nicotiana tabacum) e de koribo (Tanaecium nocturnum), e o kawabo feito de Virola elongata. Para uma breve descrição do preparo específico de cada rapé, ver Prance (1973). Para uma análise dos mitos de origem do tabaco nos povos arawá do médio Purus, ver Aparício (2017). 
5 Os Paumari especulam que aqueles não indígenas que têm o costume de abraçar podem ser um madiaboha kapamoarihi, ou seja, o duplo ou a forma humana de um perigoso cipó que mata suas vítimas estrangulando-as (Bonilla 2007:313).

6 Entre os Suruwaha, Huber observa um costume semelhante em evitar o contato físico, sobretudo com o cotovelo (Huber 2012:268). Maizza aponta igualmente para o perigo inerente ao toque entre os Jarawara com especial atenção aos jogos de futebol (2012:82).

7 Outro fator de inegável influência é a pressão exercida pelo discurso missionário, respaldado por não poucos profissionais que atuam na saúde indígena, que insiste nos supostos malefícios causados pelo uso do rapé e, de forma associada, acaba por coibir o cultivo do próprio tabaco e, evidentemente, a atuação dos pajés.

8 Esse efeito assemelha-se ao zubi batady-, "explodem os olhos" na tradução de Huber (2012:199), que se refere à modificação do olhar causada por substâncias externas ao corpo, notadamente o timbó; posteriormente o tema foi desenvolvido na análise do uso do tabaco por Aparício (2017:11, ver também 2019:284-289), que se vale da expressão "explosão do olhar". Esta explosão dos olhos é uma forma correlata, no contexto do xamanismo, de manifestar a ideia de troca de perspectiva, como sugere sua associação à condição de distanciamento/incompreensibilidade danyzy- (Huber 2012:199) e alienação, kamudyhyru/ hiniawyhyru (Huber 2012:204).

9 A menina em reclusão também tem o olhar envenenado, noki koma, semelhante ao xamã, às almas de plantas muito agressivas como a taboca teke ou como o dafi, entidade patogênica semelhante a um boi que vive nas ladeiras, na várzea e no alto de determinadas árvores. A menina permanece reclusa por quase um ano dentro do wawasa, uma casinha feita de palha construída próxima da casa de seus pais e de onde ela só sai com o rosto coberto para fazer suas necessidades e banharse, sem jamais entrar completamente na água. Somente as mulheres podem vê-la, os homens temem circular perto de sua casinha de reclusão e os meninos são alertados para evitar brincar próximo dela, isto porque o olhar da menina é extremamente patogênico, aquele que a vir ou trocar olhares com ela estará fadado a uma morte dolorosa, vomitando todo o seu sangue. Eles traduzem o nome da doença ama komini/ amaihi como tuberculose. As mulheres grávidas também ficam com o olhar alterado, de modo que, por precaução, são sempre as últimas na fila quando caminham nos varadouros. Devido à complexidade do tema, a análise do noki koma, a agência xamânica do olhar feminino, do ritual pubertário e dos processos da fabricação do corpo da mulher serão temas para um trabalho futuro.

10 Um elemento comum usado pelas meninas reclusas, de diferentes povos arawá, é um chapéu ou adorno de envira que deve cobrir seus olhos. Segundo descrição de Bonilla (2007:225) do chapéu ritual 'da'di asiaji paumari: "Le chapeau doit idéalement tomber sur les yeux de la jeune fille de façon à ce qu'elle ne puisse qu'entr'apercevoir et que ses yeux ne soient que devinés". Os chápeus rituais femininos usados pelos Jamamadi são tanto confeccionados com envira quanto com tecidos e, geralmente, cobrem o rosto inteiro da menina reclusa (Shiratori 2018). 
11 Para uma discussão sobre a polissemia deste importante conceito e seus cognatos arawá, conferir Shiratori (2018:133-136).

12 Devo esclarecer que não se trata de dizer que as plantas são mais importantes que os animais, afinal, tanto os Jamamadi quanto as Plantas são caçadores e a produtividade prática-simbólica da caça é inegável para ambos; o foco argumentativo nas plantas é tanto uma estratégia heurística, informada por dados etnográficos, quanto político-teórica em vista de experimentar o efeito provocado por essa rotação de perspectiva. Para contornar esse efeito anamórfico indesejável, a preponderância das plantas pode ser entendida menos como um privilégio de um conjunto de espécies de um reino biológico do que um saliente princípio vegetal ou vegetalidade que anima seus cosmos.

13 Com efeito, a pregnância da relação com as almas das plantas não elimina as possibilidades cosmológicas ilimitadas das explorações xamânicas; importante frisar que os contornos sociais do mundo não existem per se, mas dependem inteiramente das relações que o pajé estabelece, como bem notou Anne-Marie Colpron: [...] worlds are not permanent entities; they do not stand per se autonomously, but rather depend on the shamans' engagement and relationship to them. The shamans reveal these worlds by experiencing them, actualizing them throughout their lived interaction. In doing so, they appropriate a positioning among the many existing ones, literally incarnating these worlds (2013:376).

14 Não se trata de reforçar com essa oposição uma imagem da floresta como ambiente prístino e intocado. Trabalhos recentes de ecologia histórica (Levis et al. 2018; Clement et al. 2015) têm mostrado uma imagem antropizada de grande parte das florestas amazônicas. Baseados numa profusão de dados etnográficos, botânicos, linguísticos e arqueológicos, tais estudos mostram que a biodiversidade e sua distribuição são produtos da ação e da ocupação dos povos indígenas que por milênios têm manejado os recursos florestais, modificando seu meio substancialmente.

15 Lévi-Strauss (1986:29) já chamara a atenção para a dificuldade em distinguir o selvagem do cultivado: "nem sempre é fácil distinguir plantas silvestres de cultivadas, uma vez que existem estágios intermediários".

16 Para uma análise das categorias amosa/namosa, cujo sentido abarca as ideias de "certo", "bom", "bonito", "bem feito", contemplando as implicações para as relações de criação no parentesco entre humanos e plantas, ver Maizza (2014).

17 Para uma aproximação entre os espíritos auxiliares vaso paumari e os yamata abono jamamadi provenientes das cidades, ver Shiratori (2018:152).

$18 \mathrm{Na}$ literatura dedicada ao xamanismo indígena das terras baixas, as plantas relevantes são as chamadas plantas de poder, alucinógenas ou enteógenas, como o tabaco, o paricá, as folhas de coca ipadu (Erythroxylon coca), o cipó caapi, e, sobretudo, a ayahuasca (mistura da Banisteriposis caapi e Psychotria viridis, outras plantas podem ser adicionadas). A importância do rapé no xamanismo jamamadi, principalmente para a iniciação, não oblitera a presença das outras plantas mais "banais", ou seja, sem poder alucinatório, como as plantas cultivadas. Essa especificidade que é a dos 
povos arawá, já assinalada por Maizza (2012), aponta para outra: o universo das roças não está diretamente associado às mulheres ou exclusivamento aos temas da criação, convivialidade, afeto e parentesco, embora estes também sejam essenciais no mundo jamamadi.

19 O termo manakone e suas formas variantes nas demais línguas arawá, a saber, manakone - jarawara; manako - kulina; manakuni - deni; pavakari - paumari, aplica-se a um campo semântico amplo que se remete à noção de troca, conforme os exemplos a seguir: oka yama manakone datinahi, "qual é o preço disso?"; oka yama anini manakone datinahi, "pague o meu salário (o preço pelo meu trabalho)"; oka yama hani manakone datinaharihi, "responda minha carta"; tiwanabohani oka soho manakone nanahabani. Tiwa onahahaboni, "você matou o meu irmão mais novo, eu vou te matar como vingança (sua morte pagará a dele)"; Deoso ai ka manakone-ya nanahabane, "Deus pagou os nossos pecados". Para uma análise da categoria de troca e reciprocidade entre os Deni, ver "O manakuni dos Deni: prestações e contraprestações no rio Cuniuá (AM)" (Florido 2013) e entre os Kulina, o capítulo "O manaco na sociedade kulina: dar, receber e retribuir" (Altmann 1988:43-81).

20 A ausência de um termo genérico para "planta", categoria com alto grau de inclusão, assim como para outras categorias taxonômicas abstratas, de ampla aplicação, é mencionada por diversos autores: conferir para os Krahô (Morim de Lima 2017, nota 7), os Huaorani (Rival 2012:133), os Wajãpi (Cabral de Oliveira 2016), dentre outros.

21 A insuficiência apontada da categoria biológica planta encontra eco nas reflexões voltadas a outra categoria da natureza, a saber, a noção de espécie. Em seu estudo sobre as práticas de conhecimento relativas aos animais e à caça de macacos entre os Guajá, Garcia (2018) mostra como uma noção indígena de espécie gira em torno da ideia de "vida multiespécie" e está subordinada aos agenciamentos específicos das relações de caça e criação, ou seja, um animal criável não coincide com um animal caçável embora possam ser da mesma "espécie biológica".

22 No outro extremo da agência destruidora do noko koma, "o olhar envenenado", há o olhar dirigido aos cultivares para fazê-los crescer, que é dito katoma, sinônimo de cuidar, de promover o crescimento, de zelar, de responsabilizar-se, ou de forma enfática e contínua, notável na reduplicação dos morfemas, falam em $k a-$ katoma ou kakatomama, o olhar insistente, repetido e obstinado. Apesar de menos frequente, também é usado o v.t. kii na, olhar demoradamente, ai ka fadara ai kiiteni, "vigiamos/olhamos com atenção nossa roça".

23 A metafísica vegetal jamamadi não é um elemento essencial da realidade, mas uma atualização de formas insuspeitas de pensar ou uma estratégia para desestabilizar os esquemas analíticos em circulação pois, não é demais lembrar, as questões ontológicas são postas para resolver problemas epistemológicos, uma vez que na antropologia tais domínios não estão dissociados (Holbraad \& Pedersen 2017:ix) Logo, a formulação ontológica em termos de um "fitomorfismo" não é pensada em termos substantivos, ou seja, a ontologia não é uma metafísica do Ser, mas uma "tecnologia de descrição etnográfica" (Holbraad \& Pedersen 2017) e uma manobra 
de transformação dos nossos conceitos em vista de uma descrição outra do mundo (Viveiros de Castro 2002). Outrossim, cabe precisar, em linhas gerais, quais os sentidos admitidos pelas noções de "ontologia" e "metafísica". Evidentemente, com isso não tenho qualquer intenção de refazer os seus percursos filosóficos que, ademais, coincidem com aquele da própria filosofia ocidental. A adoção (ou contrabando) dos referidos conceitos acompanha a ênfase de diferentes trabalhos nos últimos anos por priorizar as teorias nativas em seus próprios modos de descrição e análise, passando a ser reunidas num movimento de "virada ontológica". Neste sentido, o par ontologia/ metafísica não se refere a um nível substantivo ou campo de fenômenos fundamental da realidade com categorias pertencentes ao domínio do Ser. Aqui, não se trata de passar sob revista a "mobília" do mundo, mas de seu justo oposto, ou seja, da torção do sentido filosófico comum para recusar o compromisso axiomático de fechar uma descrição do mundo; assim, as questões são formuladas em termos de ontologia e de metafísica, mas as respostas etnograficamente informadas jamais serão ontológicas ou metafísicas. Portanto, as funções gramaticais destes conceitos variam, podendo ser adjetivos ou advérbios, mas não substantivos. Talvez esta seja uma estratégia em vista de manter o horizonte da realidade sempre aberto à especulação e à dúvida.

24 As relações com as plantas cultivadas não se restringem, todavia, à consanguinidade, pois, como visto, com muitas almas de plantas a relação com os xamãs é marcada pela afinidade; ademais, no pós-mortem há uma interessante inversão da relação de filiação em conjugalidade. Estes temas serão desenvolvidos oportunamente em trabalhos futuros.

25 Tomando a liberdade de substituir onde havia "animal" por "planta", adapto as linhas abaixo de acordo com a versão jamamadi. Há uma modificação extra a ser feita, pois trocar "animal" por "planta" é apenas a metade da história. Para ser precisa, a especiação deve considerar o fato da hominização ser dependente da vegetalidade que a antecede para o caso jamamadi, ou seja, a humanidade pertence às plantas e dizer-se "homem" é um atributo embaraçosamente derivado delas. Sendo assim, modificando o trecho com as palavras em itálico - sem a pretensão de sugerir tratar-se de um fenômeno de alcance maior que sua pertinência para os Jamamadi e talvez outros povos arawá, temos: "Como todos os humanos eram plantas no começo de tudo, todos os homens serão plantas no fim de cada um: a escatologia da (des)individuação reencontra a mitologia da (pré-) especiação. Os espectros dos mortos estão, na ordem da ontogênese, como as plantas na ordem da filogênese: 'no começo, tudo era gente...'. Não é de surpreender portanto que, enquanto imagens definidas por sua disjunção relativamente a um corpo humano, os mortos sejam atraídos pelos corpos vegetais; é por isso que, na Amazônia, morrer é transformar-se em uma planta: se as almas das plantas são concebidas como tendo uma forma corporal humana prístina, é lógico que as almas dos humanos sejam concebidas como tendo um corpo vegetal póstumo..." (Viveiros de Castro 2015:288). 


\section{Referências bibliográficas}

ALTMANN, Lori. 1988. O "manaco" kulina e a economia capitalista". Trabalho de Conclusão de Curso (especialização), Pós-Graduação em Ciências Sociais, PUC, São Paulo.

APARÍCIO, Miguel. 2017. "A explosão do olhar: do tabaco nos arawa do rio Purus". Mana, 23 (1):9-35.

BONILLA, Oiara. 2007. Des proies si désirables. Soumission et prédation pour les Paumari d'Amazonie brésilienne. Tese de Doutorado, Nanterre, Université de Paris X.

CERQUEIRA, Felipe A. 2015. Os mundos, os corpos e os objetos: o xamanismo como troca entre os madihas e outros seres. Tese de Doutorado em Antropologia Social, Universidade Federal do Rio de Janeiro.

CLEMENT, Charles et al. 2015. "The domestication of Amazonia before European conquest". The Royal Society Publishing, 282 (20150813).

COCCIA, Emanuele. 2013. "Mente e matéria ou a vida das plantas". Revista Landa, 1 (2).

COLPRON, Anne-Marie. 2013. "Contact Crisis: Shamanic Explorations of Virtual and Possible Worlds". Anthropologica, 55:373-383.

DESCOLA, Philippe. 1986. La nature domestique: symbolisme et praxis dans l'écologie des Achuar. Paris: Maison des Sciences de L'Homme.

- "Societies of nature and nature of society". In: KUPER, A. (ed.), Conceptualizing society. Londres: Routledge and Kegan Paul, 107-125.

FLORIDO, Marcelo. 2013. Os Deni do Cuniuá: um estudo do parentesco. Tese de Doutorado em Antropologia Social, Universidade de São Paulo.

GARCIA, Uirá. 2018. “Macacos também choram, ou esboço para um conceito ameríndio de espécie". Revista do Instituto de Estudos Brasileiros, 69:179-204.

HARAWAY, Donna. 2008. When species meet. Minneapolis: University of Minnesota Press.

HOLBRAAD, Martin \& PEDERSEN, Mortel 2017. The ontological turn: an anthropological exposition. Cambridge: Cambridge University Press.

HUBER, Adriana. 2012. Pessoas falantes, espíritos cantores, almas-trovões. História, sociedade, xamanismo e rituais de auto-envenenamento entre os Suruwaha da Amazônia ocidental. Tese de doutorado, Universidade de Berna.

HUGH-JONES, Stephen. 1996. "Bonnes raisons ou mauvaise conscience? De l'ambivalence de certains amazoniens envers la consommation de viande". Terrain, 26:123-148.

INGOLD, Tim. 1991. "Becoming persons: consciousness and sociality in human evolution". Cultural Dynamics, 4 (3):355-78.

. 1992. "Culture and the perception of the environment". In: E. CROLL \& D. PARKIN (orgs.), Bush base: forest camp. Culture, environment and development. Londres: Rotledge. pp. 14-32.

LÉVI-STRAUSS, Claude. 1986. "O uso das plantas silvestres da América do Sul tropical". In: Darcy Ribeiro (ed.) \& Berta G. Ribeiro (coord.), Suma Etnológica Brasileira. Vol. 1: Etnobiologia. Petrópolis: Vozes/Finep. pp. 27-46.

. 2009 [1962]. O Pensamento Selvagem. São Paulo: Editora Papirus.

LEVIS et al. 2018. "How People Domesticated Amazonian Forest". Frontiers in Ecology and Evolution, 5 (171):1-21.

LIMA, Tânia S. 1996. "O dois e seu múltiplo: reflexões sobre o perspectivismo 
em uma cosmologia tupi". Mana, 2 (2): 21-47.

. "O que é um corpo". Religião \& Sociedade, 22(1): 9-20.

2005. Um peixe olhou para Mim. O povo Yudjá e a perspectiva. São Paulo: Unesp/ ISA/ Nuti.

MAIZZA, Fabiana. 2012. Cosmografia de um mundo perigoso. Espaço e relações de afinidade entre os Jarawara da Amazônia. São Paulo: Nankin. . 2014. "Sobre as crianças-planta: o cuidar e o seduzir no parentesco Jarawara". Mana, 20 (3):491-518.

MILLER, T. 2015. Bio-sociocultural aesthetics: indigenous Ramkokamekra-Canela gardening practices and varietal diversity maintenance in Maranhão. Unpublished PhD dissertation, University of Oxford.

MORIM DE LIMA, Ana Gabriela. 2017. "A cultura da batata-doce: cultivo, parentesco e ritual entre os Krahô". Mana, 23 (2):455-490.

OLIVEIRA, Joana Cabral de. 2012. Entre plantas e palavras. Modos de constituição de saberes entre os Wajãpi. Tese de Doutorado, Universidade de São Paulo.

. 2016. "Mundos de roças e florestas". Boletim do Museu Paraense Emílio Goeldi. Ciências Humanas, 11 (1):115-131.

PRANCE, Guillean. 1973. "An ethnobotanical comparation of four tribes of Amazonian indians". Acta Amazonica, 7-27.

. 1978. "The poisons and narcotics of the Dení, Paumarí, Jamamadí and Jarawara indians of the Purus river region". Revista brasileira de botânica, 1: 71-82.

RANGEL, Lucia. 1994. Os Jamamadi e as armadilhas do tempo histórico. Tese de Doutorado, PUC-SP.

RIVAL, Laura. 2001. "Seed and clone: the symbolic and social significance of bitter manioc cultivation". In: L. Rival \& N. Whitehead (eds.), Beyond the visible and the material: the amerindianization of society in the work of Peter Rivière. Oxford and New York: Oxford University Press. pp. 57-79.

. 2012. "The materiality of life: Revisiting the anthropology of nature in Amazonia". Indiana, 29:127-143.

SHIRATORI, Karen. 2018. O olhar envenenado: da metafísica vegetal jamamadi (médio Purus, AM). Tese de doutorado, Museu Nacional/UFRJ.

TAYLOR, Anne-Christine. 2000. "Le sexe de la proie: représentations jivaro du lien de parenté". L'Homme, 154-155:309-334.

VIVEIROS DE CASTRO, Eduardo. 1996. "Os pronomes cosmológicos e o perspectivismo ameríndio". Mana. Estudos de Antropologia Social, v. 2, n. 2:115-143.

2002. A inconstância da alma selvagem. São Paulo: Cosac\&Naify. . 2006. "A Floresta de cristal". Cadernos de campo, 14/15:1-382.

2015. As metafísicas canibais: elementos para uma antropologia pós-estrutural. São Paulo: Editora Cosac\&Naif/N-1 edições. 


\section{O OLHAR ENVENENADO: A PERSPECTIVA DAS PLANTAS E 0 XAMANISMO VEGETAL JAMAMADI (MÉDIO PURUS, AM)}

\begin{abstract}
Resumo
Este artigo trata da importância do universo vegetal na sociocosmologia jamamadi. Assumo o xamanismo vegetal como o fio condutor através do qual se revelam o espelhamento e o entrelaçamento entre a vida das plantas e a vida dos humanos em múltiplas dimensões. Com este intuito, abordo a iniciação xamânica, cujo objetivo final é adquirir o noko koma, "o olhar envenenado". Os contornos deste xamanismo se fazem visíveis através da relação com as almas das plantas cultivadas, yamata abono, principais auxiliares que acompanham os pajés na prática terapêutica ou, em outra perspectiva, na guerra mundial. Para a formulação do argumento proponho uma reflexão sobre os limites da categoria biológica "planta" e, por fim, sobre a caracterização do xamanismo amazônico nos termos de uma ideologia venatória, dado que a pregnância das plantas para os Jamamadi propõe questionamentos mais amplos acerca do lugar práticoconceitual atribuído aos animais.
\end{abstract}

Palavras-chave: Jamamadi, Xamanismo vegetal, Perspectivismo, Plantas cultivadas, Venenos.

\section{THE POISONED GAZE: THE PERSPECTIVE OF PLANTS AND VEGETAL SHAMANISM OF THE JAMAMADI (PURUS, AM)}




\section{LA MIRADA ENVENENADA: LA \\ PERSPECTIVA DE LAS PLANTAS \\ Y EL CHAMANISMO VEGETAL \\ JAMAMADI (MEDIO PURUS, AM)}

\section{Resumen}

Este artículo trata de la importancia del universo vegetal en la cosmología jamamadi. Asumo el chamanismo vegetal como el hilo conductor a través del cual se revela el reflejo y el entrelazamiento de la vida de las plantas y la vida de los humanos en múltiples dimensiones. Con este propósito, abordo la iniciación chamánica, cuyo objetivo final es adquirir el noko koma, "la mirada envenenada". Los contornos de este chamanismo se hacen visibles a través de la relación con las almas de las plantas cultivadas, yamata abono, principales auxiliares que acompañan a los pajes en la práctica terapéutica o, en otra perspectiva, en la "guerra mundial". Para la formulación del argumento propongo una reflexión sobre los límites de la categoría biológica "planta" y, por último, sobre la caracterización del chamanismo amazónico en términos de una ideología venatoria, dado que la pregnancia de las plantas para los Jamamadi propone cuestionamientos más amplios acerca del lugar práctico-conceptual atribuido a los animales.

Palabras clave: Jamamadi, Chamanismo vegetal, Perspectivismo, Plantas cultivadas, Venenos. 